www.jmscr.igmpublication.org Impact Factor 5.244

Index Copernicus Value: 5.88 ISSN (e)-2347-176x ISSN (p) 2455-0450 crossref DOI:_http://dx.doi.org/10.18535/jmscr/v4i6.02

\title{
A Comparative Study of Variations in Estimated Age between maxillary and mandibular teeth of an individual using TCA Method
}

\author{
Authors \\ Dr Anila Karunakaran', Dr Leena Philipose ${ }^{2}$, Dr Sivaprasad K K \\ ${ }^{1}$ Professor and Head, Dept of Dentistry, Govt Medical College, Palakkad, Kerala, India \\ ${ }^{2}$ Assistant Professor, Dept of Dentistry, Govt Medical College, Palakkad, Kerala, India \\ ${ }^{3}$ Senior Resident, Dept of Dentistry, Govt Medical College, Palakkad, Kerala, India \\ Corresponding Author \\ Dr Anila Karunakaran \\ 1-H, Federal Fort Apartments, Manapullykavu, Palakkad-678013 \\ Email id:dranilakarun@gmail.com,Ph:09847795995
}

\section{ABSTRACT}

Human age estimation is of key importance in any forensic investigation. Assessment of age by counting the total cemental annulations is well documented as a reliable method for this purpose with variations of only 2-3 years. This study is to find out if the accuracy of the estimation varies between maxillary and mandibular teeth of an individual. A maxillary and mandibular tooth each is collected from 50 patients. Longitudinal ground sections are prepared and mounted on glass slides using DPX. The image of midroot area is captured using a research microscope.and transferred to a computer monitor. Age is assessed using image analysis software. The variations from actual age of each tooth is noted. The variations of individual maxillary teeth are compared with those of corresponding mandibular teeth and significance is calculated using statistical analysis. In our study no significant difference was noted between the variations obtained from maxillary and those from mandibular teeth.

Key words: Age estimation, cemental annulations, maxillary teeth, mandibular teeth, variations

\section{Introduction}

Estimation of age is an important requirement in the identification of a deceased individual. In forensic odontology, cementum, the outer covering of the radicular dentin is found to be a reliable aid for this purpose ${ }^{1}$. It is protected from external regressive forces as it is enclosed within bone. Cementum is deposited by rhythmic apposition of calcium hydroxy apatite and this is viewed as annulations under light microscope. The age at death/extraction of the tooth is calculated by adding the number of tooth cemental annulations (TCA) with the age of eruption of the tooth as cementum deposition begins after root completion.

The estimated age using TCA shows variations even in teeth taken from the same individual. We propose that teeth of the same individual from upper and lower arches may show a definite variation in the estimated age. If such a variation is proved to exist it will enable investigators to choose between maxillary and mandibular teeth for the purpose of age estimation. 
The present study aims to find out the variations (from the actual age) of the estimated age of maxillary and mandibular teeth of the same individual using TCA method and to compare the extent of variation.

\section{Materials and Methods}

Study Design: Prospective comparative study

\section{Study Population:}

All patients reported to the Dental Out Patient Department from November 2015 to April 2016

\section{a. Inclusion criteria}

1. Patients with documented proof of age.

2. Patients of both sexes.

3. Patients with non restorable teeth.

4. Patients who choose extraction over other forms of treatment.

5. Single rooted teeth

\section{b. Exclusion criteria}

1. Deciduous and supernumerary teeth

2. Teeth with root caries

3. Patients with metabolic disorders

4. Teeth with localised periodontitis

\section{Methodology}

A set of two teeth extracted simultaneously from a patient one each from upper and lower jaws was taken as a sample. A total of 50 such samples were taken from the same number of patients. Extra teeth were collected to make up for any loss of samples during processing. Patients were selected using purposive sampling method based on inclusion and exclusion criteria. Each sample was coded to avoid bias.

The freshly extracted teeth were stored in $10 \%$ buffered formalin. Ground sections were prepared manually by first cutting the tooth longitudinally by a lathe and hand grinding by rough carborundum stone till a section of $1 \mathrm{~mm}$ is obtained. The sections were ground further using fine stone till the thickness was reduced to $0.25 \mathrm{~mm}$. The sections were cleansed with distilled water and dehydrated by immersing in $50 \%, 70 \%, 90 \%$ and $100 \%$ alcohol and then in xylene for 5 minutes each. Sections were mounted using DPX without air bubble entrapment and viewed using brightfield research microscope Olympus triocular microscope Model: $\mathrm{CH} 20 \mathrm{iTr}$ at 40x magnification (Fig 1). Only the teeth with distinctly visible cemental lines, no visible resorption or hypercementosis were taken up for the study and the others were discarded. The images were captured using research microscope. The images were photographed and transmitted to a computer monitor and TCA were counted using image analysis software Magnus Pro Image Analysis Software Version: 4.2. A pair of light and dark incremental lines was taken as one annulation corresponding to one year of the individual. The length of the total thickness of cementum (TL) from cementodentinal junction to outer edge of tooth was measured. Any two distinct adjacent annulations were selected and the length between them was also measured (tl). The number of annulations was calculated by dividing $\mathrm{TL}$ by $\mathrm{tl}$.The middle third of the root was used for the study as the cementum is mostly acellular and has less or no cementocytes. The measurements were done separately by three observers and the average was taken to reduce inter observer variability.

Number of annulations $=\mathrm{TL} / \mathrm{t} \mathrm{l}$

The age of the individual was calculated using the formula

Estimated age $=$ Eruption age of tooth + Number of annulations

The variation between actual age and estimated age was standardized for all teeth using the formula

Variation $=$ Actual age - Estimated age

\section{Statistical Analysis}

Paired ' $t$ ' test was used to assess the variation in the estimated age of maxillary and mandibular teeth of an individual. 


\section{Ethical Considerations}

Ethical clearance was obtained from the Institutional Ethical Committee as well as informed consents were obtained from individual participants.

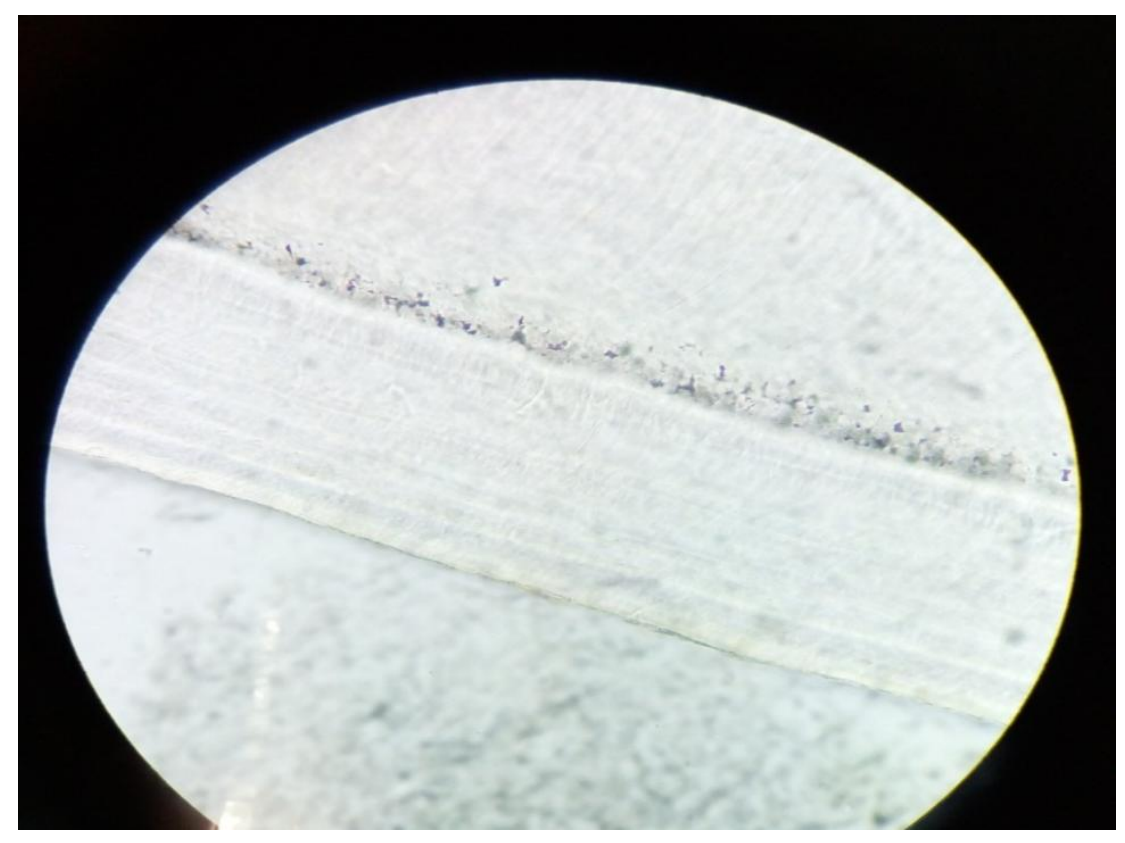

Fig 1: Incremental Lines under Bright Field Microscope

\section{Results}

Table 1: Patient Data

\begin{tabular}{|l|l|l|l|l|l|l|}
\hline S.No & Gender & Age & \multicolumn{2}{|c|}{ Maxilla } & \multicolumn{2}{c|}{ Mandible } \\
\hline & & & $\begin{array}{l}\text { TOO } \\
\text { TH }\end{array}$ & $\begin{array}{l}\text { TC } \\
\text { A }\end{array}$ & $\begin{array}{l}\text { TOO } \\
\text { TH }\end{array}$ & TCA \\
\hline 1. & Female & 54 & 13 & 49 & 45 & 50 \\
\hline 2 & Male & 49 & 13 & 47 & 33 & 46 \\
\hline 3 & Female & 47 & 11 & 45 & 33 & 44 \\
\hline 4 & Female & 47 & 12 & 43 & 34 & 42 \\
\hline 5 & Female & 36 & 11 & 33 & 41 & 32 \\
\hline 6 & Female & 40 & 11 & 38 & 41 & 37 \\
\hline 7 & Female & 54 & 12 & 52 & 43 & 53 \\
\hline 8 & Female & 54 & 13 & 51 & 45 & 50 \\
\hline 9 & Female & 54 & 14 & 52 & 44 & 53 \\
\hline 10 & Male & 48 & 13 & 45 & 33 & 44 \\
\hline 11 & Male & 48 & 12 & 46 & 35 & 45 \\
\hline 12 & Female & 47 & 13 & 46 & 34 & 45 \\
\hline 13 & Female & 53 & 11 & 51 & 41 & 50 \\
\hline 14 & Female & 53 & 11 & 52 & 41 & 50 \\
\hline 15 & Female & 53 & 21 & 51 & 31 & 52 \\
\hline 16 & Female & 53 & 13 & 50 & 42 & 49 \\
\hline 17 & Female & 20 & 25 & 18 & 35 & 19 \\
\hline 18 & Female & 18 & 13 & 17 & 35 & 16 \\
\hline 19 & Female & 43 & 12 & 41 & 42 & 42 \\
\hline 20 & Female & 45 & 22 & 41 & 32 & 40 \\
\hline 21 & Male & 51 & 23 & 50 & 43 & 49 \\
\hline
\end{tabular}




\begin{tabular}{|c|c|c|c|c|c|c|}
\hline 22 & Female & 32 & 15 & 28 & 45 & 29 \\
\hline 23 & Female & 55 & 22 & 54 & 32 & 53 \\
\hline 24 & Female & 53 & 22 & 50 & 32 & 49 \\
\hline 25 & Female & 44 & 24 & 42 & 25 & 41 \\
\hline 26. & Female & 48 & 15 & 46 & 45 & 47 \\
\hline 27 & Female & 32 & 15 & 29 & 45 & 30 \\
\hline 28 & Female & 55 & 11 & 51 & 41 & 52 \\
\hline 29 & Female & 55 & 12 & 52 & 42 & 51 \\
\hline 30 & Female & 55 & 13 & 49 & 43 & 50 \\
\hline 31 & Female & 44 & 11 & 40 & 41 & 39 \\
\hline 32 & Female & 44 & 21 & 41 & 31 & 40 \\
\hline 33 & Female & 44 & 22 & 42 & 32 & 43 \\
\hline 34 & Female & 53 & 23 & 51 & 33 & 52 \\
\hline 35 & Female & 53 & 13 & 50 & 33 & 49 \\
\hline 36 & Female & 53 & 24 & 51 & 35 & 50 \\
\hline 37 & Female & 38 & 14 & 37 & 44 & 35 \\
\hline 38 & Female & 38 & 15 & 35 & 45 & 36 \\
\hline 39 & Male & 47 & 23 & 45 & 33 & 44 \\
\hline 40 & Female & 56 & 13 & 52 & 43 & 54 \\
\hline 41 & Female & 48 & 24 & 46 & 34 & 45 \\
\hline 42 & Female & 51 & 12 & 49 & 42 & 47 \\
\hline 43 & Female & 44 & 24 & 41 & 34 & 40 \\
\hline 44 & Male & 54 & 11 & 51 & 41 & 52 \\
\hline 45 & Female & 56 & 13 & 53 & 43 & 52 \\
\hline 46 & Female & 48 & 22 & 46 & 33 & 45 \\
\hline 47 & Male & 47 & 12 & 44 & 32 & 45 \\
\hline 48 & Female & 46 & 23 & 44 & 33 & 43 \\
\hline 49 & Female & 49 & 14 & 45 & 42 & 46 \\
\hline 50 & Female & 50 & 12 & 48 & 42 & 47 \\
\hline
\end{tabular}

Table 2: Variation between Estimated Age and Actual Age

\begin{tabular}{|l|l|l|l|l|}
\hline S.No & Gender & Age & Maxilla & Mandible \\
\hline 1. & Female & 54 & 5 & 4 \\
\hline 2 & Male & 49 & 2 & 3 \\
\hline 3 & Female & 47 & 2 & 3 \\
\hline 4 & Female & 47 & 4 & 5 \\
\hline 5 & Female & 36 & 3 & 4 \\
\hline 6 & Female & 40 & 2 & 3 \\
\hline 7 & Female & 54 & 2 & 3 \\
\hline 8 & Female & 54 & 3 & 4 \\
\hline 9 & Female & 54 & 2 & 1 \\
\hline 10 & Male & 48 & 3 & 4 \\
\hline 11 & Male & 48 & 2 & 3 \\
\hline 12 & Female & 47 & 1 & 2 \\
\hline 13 & Female & 53 & 2 & 3 \\
\hline 14 & Female & 53 & 1 & 3 \\
\hline 15 & Female & 53 & 2 & 1 \\
\hline 16 & Female & 53 & 3 & 4 \\
\hline 17 & Female & 20 & 2 & 1 \\
\hline
\end{tabular}




\begin{tabular}{|c|c|c|c|c|}
\hline 18 & Female & 18 & 1 & 2 \\
\hline 19 & Female & 43 & 2 & 1 \\
\hline 20 & Female & 45 & 4 & 5 \\
\hline 21 & Male & 51 & 1 & 2 \\
\hline 22 & Female & 32 & 4 & 3 \\
\hline 23 & Female & 55 & 3 & 2 \\
\hline 24 & Female & 53 & 3 & 4 \\
\hline 25 & Female & 44 & 2 & 3 \\
\hline 26. & Female & 48 & 2 & 1 \\
\hline 27 & Female & 32 & 3 & 2 \\
\hline 28 & Female & 55 & 4 & 3 \\
\hline 29 & Female & 55 & 3 & 4 \\
\hline 30 & Female & 55 & 6 & 5 \\
\hline 31 & Female & 44 & 4 & 5 \\
\hline 32 & Female & 44 & 3 & 4 \\
\hline 33 & Female & 44 & 2 & 1 \\
\hline 34 & Female & 53 & 2 & 1 \\
\hline 35 & Female & 53 & 3 & 4 \\
\hline 36 & Female & 53 & 2 & 3 \\
\hline 37 & Female & 38 & 1 & 3 \\
\hline 38 & Female & 38 & 3 & 2 \\
\hline 39 & Male & 47 & 2 & 3 \\
\hline 40 & Female & 56 & 4 & 2 \\
\hline 41 & Female & 48 & 2 & 3 \\
\hline 42 & Female & 51 & 2 & 4 \\
\hline 43 & Female & 44 & 3 & 4 \\
\hline 44 & Male & 54 & 3 & 2 \\
\hline 45 & Female & 56 & 3 & 4 \\
\hline 46 & Female & 48 & 2 & 3 \\
\hline 47 & Male & 47 & 3 & 2 \\
\hline 48 & Female & 46 & 2 & 3 \\
\hline 49 & Female & 49 & 4 & 3 \\
\hline 50 & Female & 50 & 2 & 3 \\
\hline
\end{tabular}

Table 3: Comparison of Variations

\begin{tabular}{|c|c|c|c|c|c|c|c|c|}
\hline & \multicolumn{5}{|c|}{ Paired Differences } & \multirow[b]{3}{*}{$\mathrm{t}$} & \multirow[b]{3}{*}{ df } & \multirow[b]{3}{*}{ Sig. (2-tailed) } \\
\hline & \multirow[b]{2}{*}{ Mean } & \multirow{2}{*}{\begin{tabular}{|l} 
Std. \\
Deviation
\end{tabular}} & \multirow{2}{*}{$\begin{array}{ll}\text { Std. } & \text { Error } \\
\text { Mean } & \\
\end{array}$} & \multicolumn{2}{|c|}{$\begin{array}{l}95 \% \text { Confidence Interval } \\
\text { of the Difference }\end{array}$} & & & \\
\hline & & & & Lower & Upper & & & \\
\hline Variations in TCA & .30000 & 1.11117 & .15714 & -.01579 & .61579 & 1.909 & 49 & .062 \\
\hline
\end{tabular}

*Significant at $\mathrm{P}<0.05$ 


\section{Discussion}

In forensic odontology, cementum is found to be a reliable aid for estimation of age ${ }^{1}$. The age at death/extraction of the tooth is calculated by adding the number of tooth cemental annulations (TCA) with the age of eruption of the tooth as cementum deposition begins after root completion. The estimated age using TCA shows an error margin of 2 to 5 years ${ }^{1,2}$ and the error is not constant even in teeth taken from the same individual $^{2}$. TCA have been studied for age estimation by many authors. The condition of the tooth under study needs to be noted as conflicting reports are seen to be made on the accuracy when periodontally involved teeth are used ${ }^{3,4}$. Periodontal status is found to increase the estimated age in some studies ${ }^{3}$ but since we are comparing two teeth from the same individual, the periodontal status is not expected to affect the outcome of the study. Most authors are in agreement that the mid portion of the root is best suited for study as there is less interference by cementocytes. Reliability of age estimation decreased considerably in older age groups probably due to slower deposition of cementum. Some authors have questioned the accuracy of this technique for ages above $55^{4,5}$. P. Aggarwal et al have said that there is no difference in the error of estimation with gender, tooth type or $\operatorname{arch}^{4}$.

The present study comprised of 50 patients of that 43 were female and 7 were male. Most of the patients were above 40 years. In the present study we have used light optical method for age estimation using TCA method. Some studies have advocated that light optical method do not give satisfactory results in age estimation. The present study supports that light optical method is a reliable aid in age estimation using TCA method ${ }^{6-}$ ${ }^{13}$.In our study the variations in estimated age from the actual age in both maxillary and mandibular teeth were in the range of 1 to 5 years (Table 1,2). The comparison of variations in actual age and estimated age, in maxillary arch with that of the same in mandibular arch were not statistically significant $\mathrm{p}=0.62$ (Table 3 ). The study shows that age estimation of an individual using TCA method can be carried out using either maxillary or mandibular single rooted tooth .This is in accordance with the findings of P. Aggarwal et $\mathrm{al}^{4}$.

\section{Conclusion}

In the present study the variations from actual age in maxillary teeth and mandibular teeth did not give significant results when compared. Hence it may be concluded that teeth from either jaw may be used for age estimation and no greater accuracy may be expected from any one jaw. We have used a single rooted maxillary tooth and mandibular tooth from each subject. It is suggested that further studies may be carried out using a larger sample size and more number of teeth from each individual.

\section{References}

1. Avadhani A, Tupkari J V, Khambaty A, Sardar M. Cementum annulations and age determination. J Forensic Dent Sci 2009;1:73-6

2. Wittwer-Backofen U. Age estimation using tooth cementum annulation.Methods Mol Biol. 2012;915:129-43.

3. Dias PE, Beaini TL Melani RF . Age Estimation From Dental Cementum Incremental Lines and Periodontal Disease J Forensic Odontostomatol 2010;28:1:1321

4. Pooja Aggarwal ,Susmita Saxena Puja Bansal . Incremental Lines in root cementum of human teeth: An approach to their role in age estimation using polarizing microscopy IJDR 2008 Vol 19 Issue 4 Page 326-330

5. Priya Gupta, Harshaminder Kaur, Madhu Shankari G.S , Manveen Kaur Jawand, Nita Sahi. Human Age Estimation from Tooth Cementum and Dentine. Journal of clinical and Diagnostic Rresearch 2014 April Vol -8 (4): ZC07-ZC10 
6. Renz H, Schaefer V, Duschner H, Radlanski RJ. Incremental Lines in Root Cementum of Human Teeth: An Approach to their Ultrastructural nature by microscopy. Adv. Dent. Res. 1997; 11: 472-7.

7. Leiberman DE. The biological basis for seasonal increments in dental cementum and their application to archaeological research. J Archaeo Sc 1994;21:525-39.

8. Wada K, Ohtaishi N, Hachiya N. Determination of age in the Japanese monkey from growth layers in the dental cementum. Primates 1978; 19:775-84.

9. Gasaway WC, Harkness DB, Rausch RA. Accuracy of Moose Age Determinations from Incisor Cementum Layers, J Wldlf Mngmt 1978;42:558-63.

10. Lindskog S. Formation of intermediate cementum I: early mineralisation of aprismatic enamel and intermediate cementum in monkey. J Craniofacial Gen and Dev Biol. 1982 a;2:147-60

11. Stoneberg RP, Jonkel CJ. Age Determination of Black Bears by Cementum Layers. ,J Wldlf Mngmt 1966 ;30:411-4.

12. Stott GG, Sis RF, Levy BM. Cementum annulation as an age criterion in Forensic Dentistry. J Dent Res 1982; 61:814-7.

13. Condon et al. Cementum Annulation and Age Determination in Homo sapiens.II. Estimates and Accuracy. Am J Phys Anthropol 1986; 71:321-330. 